\title{
Supplementation of cows with linseed: effects on antral follicle count, oocyte quality, and nutritional and plasma metabolite parameters
}

\section{Suplementação de fêmeas girolando com linhaça: efeitos sobre contagem de folículos antrais, qualidade oocitária, parâmetros nutricionais e metabólitos plasmáticos}

\author{
Christopher Junior Tavares Cardoso ${ }^{1 *}$; Ana Caroline Bini de Lima ${ }^{1}$; Wilian \\ Aparecido Leite da Silva²; Mirela Brochado Souza-Cáceres ${ }^{3}$; Daniela Moraes \\ Pereira $^{1}$; Marcus Vinicius Morais de Oliveira ${ }^{4}$; Ériklis Nogueira ${ }^{5}$; Fabiana de \\ Andrade Melo-Sterza ${ }^{4}$
}

\begin{abstract}
Linseed is distinguished by its composition of fatty acids, which are rich in unsaturated acids, and by the slow release of oil in the rumen, consequently providing a greater amount of lipids of interest for intestinal absorption. The aim of this study was to evaluate the effect of linseed supplementation on the antral follicle count (AFC) and oocyte quality of Girolando cows, as well as their digestive parameters and plasma metabolite. Twelve Girolando cows were used in the study and were randomly distributed in two experimental groups: control $(\mathrm{CTL}, \mathrm{n}=6)$ and linseed (LINS, $\mathrm{n}=6)$ ). During the 126 days of supplementation, seven transvaginal ultrasound-guided ovum pick-up (OPU) sessions were performed at intervals of 21 days. AFC was performed in each OPU session. The cows fed with linseed showed no significant difference in the dry matter coefficient of digestibility (63.11 and 62.88), crude protein (62.7 and 55.26), neutral detergent fiber (NDF; 75.36 and 77.15), or acid detergent fiber (ADF; 72.45 and 74.77) for LINS and CTL, respectively. On the contrary, a higher level of ethereal extract was observed for LINS (69.31 vs. 40.7). There was no effect $(p>0.05)$ of lipid supplementation on plasma metabolite between groups and OPU sessions. There was no difference $(p>0.05)$ in the mean number of antral follicles (CTL: $31.14 \pm 1.97$; LINS: $25.52 \pm 2.68$ ), cumulus oocyte complexes recovered (CTL: $6.45 \pm 1.66$; LINS: $5.28 \pm 1.18$ ), or oocyte quality (CTL: $60.48 \% \pm 8.46$; LINS: $64.54 \% \pm 7.77$ ). The supplementation of $800 \mathrm{~g}$ of linseed in the diet of Girolando cows did not alter the apparent digestibility of nutrients, AFC, or quality of oocytes obtained by OPU.
\end{abstract}

Key words: Polyunsaturated fatty acid. Reproduction. Digestibility.

\footnotetext{
${ }^{1}$ Discentes do Curso de Mestrado, Programa de Pós-Graduação em Zootecnia, Universidade Estadual de Mato Grosso do Sul, UEMS, Aquidauana, MS, Brasil. E-mail: christopher.zootecnista@gmail.com; carolinebini@hotmail.com; daniela.mrs@ hotmail.com

2 Discente, Programa de Pós-Graduação em Ciência Animal, UFMS, Campo Grande, MS, Brasil. E-mail: wilian.leite@live.com

3 Discente, Programa de Pós-Graduação em Ciência Animal, Universidade Estadual de Londrina, UEL, Londrina, PR, Brasil. E-mail: mirela.mbs@gmail.com

4 Profs., Programa de Pós-Graduação em Zootecnia, UEMS, Aquidauana, MS, Brasil. E-mail: marcusvmo@uems.br; fabiana. sterza@uems.br

5 Pesquisador A, Empresa Brasileira de Pesquisa Agropecuária, EMBRAPA Pantanal, Corumbá, MS, Brasil. E-mail: eriklis. nogueira@embrapa.br

* Author for correspondence
} 


\title{
Resumo
}

\begin{abstract}
A linhaça destaca-se pela composição de ácidos graxos insaturados e por apresentar lenta liberação do óleo no rúmen e consequentemente fornecendo maior quantidade de lipídios de interesse para absorção intestinal. O objetivo deste estudo foi avaliar o efeito da suplementação com linhaça sobre a contagem de folículos antrais e a qualidade oocitária de vacas Girolando, bem como parâmetros digestivos e metabólitos plasmáticos. Foram utilizadas doze fêmeas bovinas da raça Girolando distribuídas aleatoriamente em 2 grupos experimentais: controle $(C T L n=6)$ e linhaça (LINS, $n=6$ ). Durante os 126 dias de suplementação foram realizadas 7 sessões de aspiração folicular guiada por ultrassonografia (OPU) com intervalo de 21 dias entre si. A cada sessão de OPU a CFA era realizada. Os animais alimentados com linhaça não apresentaram diferença no coeficiente de digestibilidade de matéria seca $(63,11$ vs. 62,88$)$, proteína bruta $(62,7$ vs. 55,26$)$, fibra em detergente neutro $(75,36$ vs. $77,15)$, fibra em detergente ácido $(72,45$ vs. 74,77$)$ para LINS e CTL respectivamente. Por outro lado, os níveis de extrato etéreo foram superiores para LINS $(69,31$ vs. 40,7). Não houve efeito $(P>0,05)$ da suplementação lipídica sobre os metabólitos plasmáticos entre os grupos e as sessões de OPU. Não houve diferença $(\mathrm{P}>0,05)$ no número médio de folículos antrais $(31,14 \pm 1,97$ vs. $25,52 \pm 2,68)$, COCs recuperados $(6,45 \pm 1,66$ vs. $5,28 \pm 1,18)$ e na qualidade dos oócitos $(60,48 \% \pm 8,46$ vs. $64,54 \% \pm 7,77)$ para LINS e CTL respectivamente. A suplementação de $800 \mathrm{~g}$ de linhaça na dieta de vacas Girolando não alterou a digestibilidade aparente dos nutrientes, bem como o número e a qualidade dos oócitos obtidos por OPU.
\end{abstract}

Palavras-chave: Ácido graxo poli-insaturado. Reprodução. Digestibilidade.

\section{Introduction}

The inclusion of lipids in the diet of ruminants can interfere with the digestion of other nutrients, as the added fat itself (JENKINS; JENNY, 1989). These effects can occur in several ways, such as through physical coverage of dietary fiber, which prevents the attack of microorganisms, and through modification of the microbial population of the rumen owing to the toxic effects of fat on ruminal microorganisms (PALMQUIST; JENKINS, 1980; CAVALIERI et al., 2005).

Lipids also have direct effects on reproduction, improving the fertility of animals in different situations, such as ovulation and pregnancy rate (GUARDIEIRO et al., 2011). Effects of fatty acids on ovarian follicular development, corpus luteum, and oocyte quality have been observed (STAPLES et al., 1998). Although the effects on follicular development resulting from changes in nutrition for prolonged periods, particularly dietary restriction, have been studied extensively in animals, the effects of polyunsaturated fatty acid (PUFA) supplementation are less understood.
The effects of the supply of fat on ovarian follicular count have been observed for dairy and beef cattle in all stages of lactation (GUARDIEIRO et al., 2011; FOULADI-NASHTA et al., 2009). Some authors have observed an increase in follicular count as a result of fat supplementation with Megalac ${ }^{\circledR}$ in beef cows (NOGUEIRA et al., 2012).

In addition, when PUFAs are included in the diet, they have been found to increase circulating concentrations of progesterone (LOPES et al., 2009), PGF $2 \alpha$ (MATTOS et al., 2000), and IGF-1, as well as embryonic quality (CERRI et al., 2009; SARTORI et al., 2016).

Dietary fatty acids alter the fatty acid (FA) composition of cumulus cells, granulosa cells, and oocytes, which may be relevant for oocyte quality (KIM et al., 2001). In another study, when feeding PUFAs to sheep, changes in phospholipid FA composition in plasma and cumulus cells as well as changes in oocyte membrane properties and quality were observed (ZERON et al., 2002). In the same study, small changes in the FA composition of 
oocytes were found, and higher numbers of grade 1 oocytes were collected from PUFA-supplemented ewes (ZERON et al., 2002). Kim et al. (2001) also found differences in FA composition between grade 1 and grade 2/3 oocytes, suggesting that the appearance of the ooplasm may reflect lipid and FA content. These differences did not directly influence oocyte maturation, but effects on oocyte competence cannot be discounted and might be responsible for differences in fertilization rate and developmental potential (KIM et al., 2001).

In this context, several studies were performed to evaluate the effect of different sources of fatty acids, which were provided to increase energy density in the diet, on reproductive performance in dairy cattle. Some studied sources of FA include soybean oil (PONTER et al., 2012), sunflower seeds (THANGAVELU et al., 2007), and linseed (FOULADI-NASHTA et al., 2009). Linseed is rich in polyunsaturated fatty acids, especially linolenic acid, and, because it is in the grain form, linseed oil may have a slower release, thereby reducing ruminal biohydrogenation (CAVALIERI et al., 2005). Our hypothesis was that supplementation of PUFAs in the donor diet might promote an increase in antral follicle count (AFC) and improve oocyte quality depending on the time of supplementation.

Based on this, the aim of this study was to evaluate the effect of linseed supplementation on AFC and oocyte quality in Girolando cows, as well as apparent digestibility and plasma metabolites (glucose, albumin, and cholesterol).

\section{Material and Methods}

The experiment was carried out at the following geographical coordinates: altitude 181 m, latitude $20^{\circ} 28^{\prime}$ south and longitude 55\% $47^{\prime}$ west, in Aquidauana, Mato Grosso do Sul, Brazil, between December 2014 and June 2015. The Committee for Ethics in Animal Experimentation from Universidade Estadual de Mato Grosso do
Sul approved all the procedures performed in the experiments (Protocol No. 012/2014).

\section{Animals and experimental design}

Twelve cows of the Girolando breed (3/4 Holstein $\times 1 / 4$ Gir), which were non-pregnant and non-lactating, $5.16 \pm 1.97$ years old, $558.41 \pm 67.6$ $\mathrm{kg}$ body weight, and with a body condition score (BCS) of $4.06 \pm 0.41$ (HOUGHTON et al., 1990), were used in this experiment.

The animals were maintained in a rotational grazing system in six paddocks of 1.2 hectares each, planted with Mombasa grass (Panicum maximum $s p$.), and with free access to water and mineral supplementation (Montana $87^{\circledR}$, Montana Mineral Supplements and Rations Ltd., Jardim, MS, Brazil).

The cows were divided into two homogeneous groups, considering mean body weight, age, BCS, and mean AFC. The cows were assigned to receive the experimental diets, which consisted of the control diet ( $\mathrm{n}=6$; no additional linseed) and LINS ( $\mathrm{n}=6$, additional $800 \mathrm{~g}$ of linseed - Natubom, 7M Foods, Campo Grande, MS, Brazil). Initially, a 15day adaptation period was established to stabilize the desired consumption amount. After this period, the animals received $0.8 \mathrm{~kg}$ linseed/day for 126 days.

\section{Food management and sample collection}

The animals had free access to Mombasa grass, the chemical composition of which was $29 \%$ dry matter (DM), $7.5 \%$ crude protein (CP), $66.2 \%$ neutral detergent fiber (NDF), 31\% acid detergent fiber (ADF), $1.5 \%$ ethereal extract (EE), and 9.6\% mineral matter (MM). The linseed for the supplemented group was supplied once daily during the morning period; the chemical composition and fatty acid profile of the supplement are described in Table 1. The analysis was carried out in the Nutrition Laboratory of Catholic University Don Bosco (UCDB), Campo Grande - MS, Brazil. 
All animals were handled together. To eliminate the environmental effects of management, all the animals were taken to the corral daily, and only the animals in the LINS group received the experimental diet. The experimental diet was supplied individually so that the animals consumed the desired amount without competition, and they were only released after consuming all the product supplied to ensure total consumption of the product.

Table 1. Bromatological composition and fatty acids present in linseed.

\begin{tabular}{lc}
\hline Components & Values \\
\hline DM (\%) & 92.90 \\
CP (\%) & 21.99 \\
NDF (\%) & 40.09 \\
ADF (\%) & 20.59 \\
EE (\%) & 27.35 \\
MM (\%) & 7.03 \\
\hline & Fatty acids $\left(\mathrm{g} \mathrm{kg}^{-1}\right)$ \\
\hline C12:0 - Lauric acid & $0.12 \pm 0.01$ \\
C14:0 - Myristic acid & $0.24 \pm 0.01$ \\
C16:0 - Palmitic acid & $6.20 \pm 0.12$ \\
C16:1 - Palmitoleic acid & $0.11 \pm 0.01$ \\
C18:0 - Stearic acid & $3.21 \pm 0.03$ \\
C18:1 (trans) - Elaidic acid & $0.25 \pm 0.02$ \\
C18:1 - Oleic acid & $16.32 \pm 0.05$ \\
C18:2 - Linoleic acid & $15.68 \pm 0.01$ \\
C18:3n3 - Linolenicacid (omega 3) & $51.89 \pm 0.14$ \\
C20:0 - Arachidic acid & $0.10 \pm 0.01$ \\
C20:1 - Cis-11-eicosenic acid & $0.16 \pm 0.04$ \\
C22:0 - Behenic acid & $0.13 \pm 0.01$ \\
\hline Polyunsaturated fatty acids & $69.95 \pm 5.68$ \\
Monounsaturated fatty acids & $16.85 \pm 0.09$ \\
Saturated Fatty Acids & $10.00 \pm 0.07$ \\
\hline Dry & \\
\hline
\end{tabular}

Dry matter (DM); crude protein (PB); ethereal extract (EE); neutral detergent insoluble fiber (NDF); acid detergent insoluble fiber (FDA); mineral matter (MM).

In this experiment, it was inferred that the Mombasa grass presented a high forage yield, with an initial biomass production of $4.830 \mathrm{~kg} \mathrm{DM} /$ hectare, a forage accumulation rate of $188 \mathrm{~kg} \mathrm{DM} /$ hectare/day, and a residue after grazing of $2.220 \mathrm{~kg}$ $\mathrm{DM} /$ hectare, with a mean proportion of the fractions in the dry matter of $59 \%$ leaf, $33 \%$ stalk, and $8 \%$ senescent material.
The biomass of the Mombasa grass in the picket was determined through the exclusion cage method, where on the day the animals entered, one iron cage was placed, wired with a screen of $4 \mathrm{~m}^{2}$ (2.5 and $2.0 \mathrm{~m}$ width and height, respectively), and the grass near the ground on the left side of the cage was collected. On the day the animals left the picket, the grass on the adjacent right side of the cage was 
collected, in addition to a sample from an area of equal size outside the cage (grazed grass residue). After weighing the grass, the leaf fractions, stalk, and senescent material were separated. The daily dry matter accumulation rate (TAD) was calculated according to the method described by Campbell (1966).

\section{Reproductive evaluation}

During the experimental period, seven sessions of transvaginal ultrasound-guided ovum pick-up (OPU) were performed, the first being performed one day before starting the animal's adaptation period. D0 was the day after the end of the adaptation, in which the animals started to consume the desired amount of linseed. From D0 on, 6 OPU sessions were performed in both groups, with a mean interval of 21 days (Figure 1). For statistical analysis, only the data from the 6 OPUs performed after the adaptation period were used.

Figure 1. Schematic representation of the days in which the donors were submitted to the OPU during the experimental period.

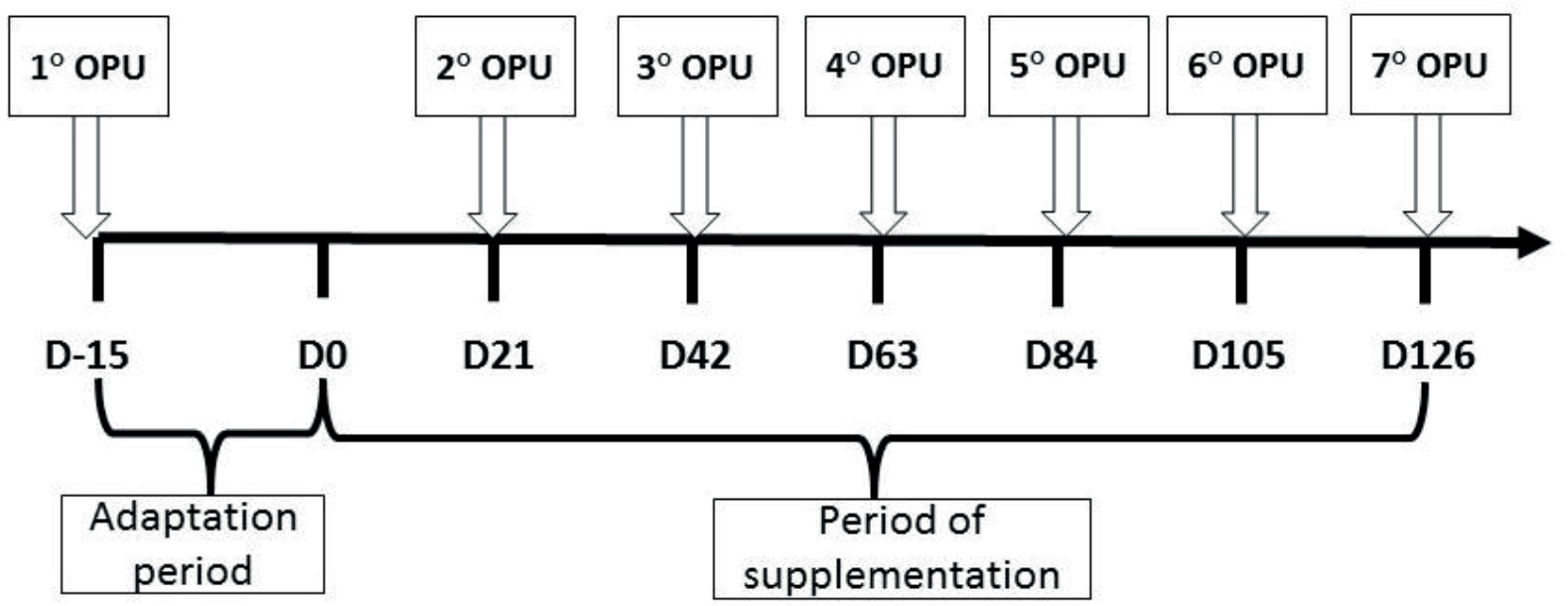

To carry out the AFC and OPU procedure, $3 \mathrm{~mL}$ of lidocaine $\left(\right.$ Lidovet $^{\circledR}$, Bravet LTDA Laboratory, Rio de Janeiro, RJ, Brazil) was applied to the intervertebral space between the last sacral vertebra and the first coccygeal vertebra, and then transvaginal ultrasonography was performed using ultrasound equipment attached to a $7.5-\mathrm{MHz}$ micro-convex transducer (Aquila ${ }^{\circledR}$, Pie Medical, Maastricht, The Netherlands). Feces were removed from the rectum, and the perianal area was washed using tap water. Follicles of $\geq 3 \mathrm{~mm}$ diameter in both ovaries were counted to characterize the AFC. To count the follicles, the operator made a slow rotation of about $180^{\circ}$ to make sure all follicles were counted at once. Immediately after counting, with the help of a "cineloop" (an ultrasound instrument that records images in few seconds), AFC was checked. Then, all follicles visualized in the ovaries were punctured to obtain cumulus oocyte complexes (COCs). A $20 \mathrm{G}$ gauge needle $\left(50 \mathrm{~mm} \times 9 \mathrm{~mm}\right.$; Terumo ${ }^{\circledR}$, Bio Brazil, São Paulo, Brazil) coupled to a microconvex transducer with a $80 \mathrm{~mm} / \mathrm{Hg}$ vacuum suction pump was used (WTA Watanabe Tecnologia Aplicada Ltda., Cravinhos, SP, Brazil). The follicular content was recovered from a Teflon circuit (WTA Watanabe Tecnologia Aplicada Ltda.) of $2 \mathrm{~mm}$ internal diameter 
and $80 \mathrm{~cm}$ in length, attaching the needle directly to a $50 \mathrm{~mL}$ plastic tube containing $5 \mathrm{~mL}$ of collection medium, which consisted of DPBS supplemented with 1\% fetal bovine serum (Gibco BRL) and 20 IU sodium heparin $\mathrm{mL}^{-1}$ (Hepamax ${ }^{\circledR}$, Blau Pharmaceuticals, Cotia, SP, Brazil) at a temperature of $37^{\circ} \mathrm{C}$. The collected material was filtered (WTA Watanabe Tecnologia Aplicada Ltda.) and washed in the suction solution described above. The recovered COCs were evaluated under stereomicroscopy and classified as viable or non-viable. Grade I and II COCs (cytoplasmic oocytes with homogeneous granulations and at least three layers of compact cumulus cells) were considered viable.

\section{Nutrient digestibility}

The Mombasa grass dry matter intake by the animals was determined indirectly using indigestible $\mathrm{ADF}$ as an internal marker, according to the method described by Cochran et al. (1986).

Grass samples were collected from the entrance and exit of each paddock at different periods throughout the experiment using the simulated grazing technique described by Clipes et al. (2005). The collection was performed for a period of $40 \mathrm{~min}$, starting before feeding. The animals were monitored from less than $2 \mathrm{~m}$ to observe their grazing habits and preference for the structural components of the forage. Thus, in a synchronized manner with the cows, forage was manually harvested. Subsequently, the material was homogenized and a subsample of approximately 500 $\mathrm{g}$ was stored for further bromatological evaluation. Feces samples were collected directly from the animal's rectal bulb, always on the date of the OPUs. The total fecal production of the animals was determined by performing a total collection of feces in a period of $24 \mathrm{~h}$, which was carried out on the last day of feeding.

The apparent digestibility coefficients of the nutrients in the total digestive tract (DATT) were calculated by the difference between the amount of nutrient consumed and the amount excreted in the feces of the same nutrient using the following equation: DATT $(\%)=[((\mathrm{DM}$ ingested $\times \%$ Nutrient $)$ $-(\mathrm{DM}$ excreted $\times \%$ Nutrient $) /(\mathrm{DM}$ ingested $\times \%$ Nutrient) $) \times 100]$.

\section{Sample analysis}

The samples of grass and feces were pre-dried in a forced ventilation oven $\left(65^{\circ} \mathrm{C}, 48 \mathrm{~h}\right)$ and then ground to $2 \mathrm{~mm}$ in a Wiley mill, placed in plastic pots, identified, and stored for further determination of dry matter (DM) and crude protein (CP) according to the methodology proposed by Silva and Queiroz (1981). The levels of NDF and ADF were determined according to the method described by Van Soest et al. (1991), and the contents of ethereal extract (EE) and MM were determined according to the method described by Silva and Queiroz (1981).

The lipid profile of linseed was determined according to the methodology of Nunes et al. (2015), using gas chromatography (Agilent 6890N, Ramsey - MN, USA) to obtain individual peaks of fatty acid methyl esters. The analysis was carried out in the Nutrition Laboratory, Catholic University Don Bosco (UCDB), Campo Grande-MS, Brazil.

At each OPU session, blood samples were collected from all animals via venipuncture (coccygeal vein) into $10 \mathrm{~mL}$ vacutainer tubes for quantification of glucose, albumin, and cholesterol. After collection, they were centrifuged at $3000 \mathrm{rpm}$ for $10 \mathrm{~min}$ to separate the serum, and then stored at $-20{ }^{\circ} \mathrm{C}$ until further analysis as described by Cardoso et al. (2018a).

The levels of total cholesterol (enzymatic colorimetric method), albumin (enzymatic colorimetric-bromocresol green method), and glucose (enzyme-hexokinase method with commercial kits) were quantified using $\operatorname{COBAS}^{\circledR}$ automated spectrophotometry (Roche-Hitachi). All analyses of plasma metabolites were performed at the Laboratory of Veterinary Clinical Pathology, at the Federal University of Mato Grosso do Sul. 


\section{Statistical analysis}

The study design was completely randomized with two treatments. For each variable studied, the normality of variance distribution was verified using the Shapiro-Wilk test. The data were transformed if necessary. For the variables of dry matter intake, nutrient digestibility, AFC, and oocytes quality, the PROC GLIMMIX procedure was used. The model included the fixed treatment effects, OPU day and interaction treatment vs. OPU day, random effect of animal tested within treatment, and residual error. Blood metabolite data were analyzed as repeated data using the PROC MIXED procedure. The SAS System for Windows (Statistical Analysis System, version 9.3) was used for all analyses. The data are presented in average, and for all analyses, differences of $p \leq 0.05$ were considered significant.

\section{Results}

Animals fed with linseed had an increase in apparent digestibility of $\mathrm{EE}(P<0.0001)$, and no effects $(p>0.05)$ of treatment were observed on DM, CP, NDF, or ADF digestibility (Table 2). There was no effect $(p>0.05)$ of the addition of linseed on plasma concentrations of glucose (CTL: $59.4 \mathrm{mg} / \mathrm{dL}$ vs LINS: $59.2 \mathrm{mg} / \mathrm{dL}$ ), albumin (CTL: $3.61 \mathrm{~g} / \mathrm{d} \mathrm{L}$ vs LINS: $3.5 \mathrm{~g} / \mathrm{dL}$ ), or cholesterol (CTL: $104.1 \mathrm{mg}$ / dL vs LINS: $116.3 \mathrm{mg} / \mathrm{dL}$; Figure 2). The observed values are considered normal for cattle (glucose: 45.00 to $75.00 \mathrm{mg} / \mathrm{dL}$, albumin: 3.3 to $3.55 \mathrm{~g} / \mathrm{dL}$, and cholesterol: 80 and $120 \mathrm{mg} / \mathrm{dL}$ ).

$\mathrm{AFC}$ and oocyte quality showed no interaction among OPU sessions and treatment, and the averages of all OPU sessions were grouped per treatment. No difference was observed in AFC, recovered COCs, viable oocytes, or quality rate $(p>0.05)$ between the groups (Table 3).

Table 2. Daily intake of DM and diet digestibility coefficients of bovine females managed under grazing and treated with linseed.

\begin{tabular}{cccc}
\hline \multirow{2}{*}{ Parameters } & \multicolumn{2}{c}{ Diets } & \multirow{2}{*}{ P Value } \\
\cline { 2 - 3 } & Control & Linseed & 0.5452 \\
DMI - kg/day & $12.67 \pm 0.33$ & $12.92 \pm 0.23$ & 0.8394 \\
DMD (\%) & $62.88 \pm 0.96$ & $63.11 \pm 0.97$ & 0.2541 \\
DCP (\%) & $55.26 \pm 6.35$ & $62.70 \pm 6.37$ & 0.0579 \\
DNDF (\%) & $77.15 \pm 0.72$ & $75.36 \pm 0.69$ & 0.1194 \\
DADF (\%) & $74.77 \pm 1.05$ & $72.45 \pm 1.11$ & $<0.0001$ \\
DEE (\%) & $40.70 \pm 0.22$ & $69.31 \pm 0.21$ & 0.2179 \\
TDN (\%) & $62.89 \pm 1.82$ & $63.83 \pm 2.00$ & \\
\hline
\end{tabular}

Daily dry matter intake (DMI), dry matter digestibility \% (DMD); digestibility crude protein (DCP); digestibility neutral detergent fiber (DNDF); digestibility acid detergent fiber (DADF); digestibility ethereal extract (DEE) and total digestible nutrients (TDN). 
Figure 2. Serum concentration of metabolites in the Girolando cows maintained under grazing regime on the Mombasa grass with linseed supplementation.
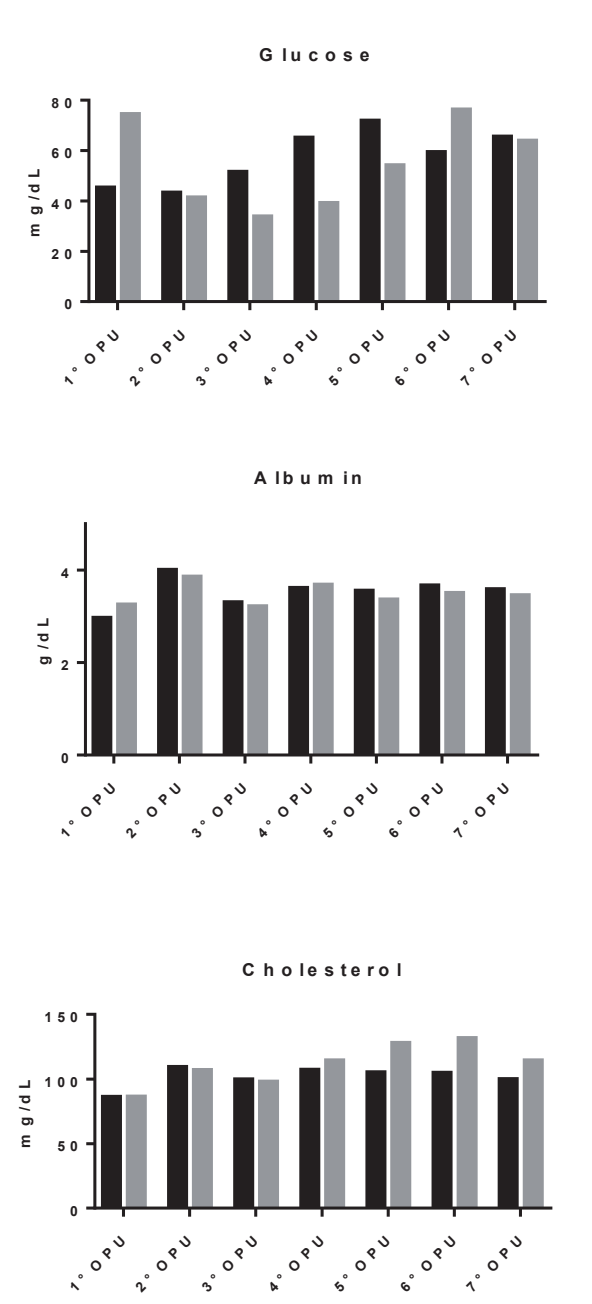

Table 3. Average \pm SD of the antral follicle count (AFC) number of oocytes recovered (viable and nonviable) and viability rate of Girolando cows supplemented with linseed (LINS) or (CONTR).

\begin{tabular}{lccc}
\hline Variables* & CONTR $(\mathrm{n}=6)$ & LINS $(\mathrm{n}=6)$ & P Value \\
\hline AFC (n) & $31.14 \pm 1.97$ & $25.52 \pm 2.68$ & 0.7136 \\
Total oocytes recovered (n) & $6.45 \pm 1.66$ & $5.28 \pm 1.18$ & 0.3495 \\
Oocytes (grades I and II) (n) & $4.16 \pm 1.04$ & $3.64 \pm 0.59$ & 0.2853 \\
Non-viable oocytes (n) & $2.28 \pm 0.85$ & $1.64 \pm 0.96$ & 0.2925 \\
Viability rate (\%) & $60.48 \pm 8.46$ & $64.54 \pm 7.77$ & 0.2209 \\
\hline
\end{tabular}

* No significant difference was observed between treatments $(\mathrm{P}>0.05)$.

\section{Discussion}

This study tested the addition of linseed as a source of lipids in the animals' diet. Linseed is a product rich in PUFAs of the n-3 ( $\alpha$-linolenic) family and less rich in the n-6 (linoleic) family. When supplied as grain, it is thought that the oil present in linseed has a slower release, thereby decreasing ruminal biohydrogenation (CAVALIERI et al., 2005). 
Though it had a high lipid content, the inclusion of $800 \mathrm{~g}$ of linseed in the diet of Girolando cows did not significantly affect the intake of dry matter and/ or nutrients, digestibility of nutrients, or metabolic parameters, indicating that the linseed has low ruminal degradability, with little effect on the ruminal microbiota, especially cellulolytic bacteria, or the lipolysis and biohydrogenation of the fatty acids present in linseed. However, an increase was observed in the apparent digestibility of the EE, owing to the high availability of the polyunsaturated fatty acids present in the linseed at the intestinal level, which passed through unharmed by the ruminal environment and reached the duodenumjejunum. They were potentially solubilized by bile salts and broken down by lipolytic enzymes, with subsequent absorption by enterocyte cells followed by re-esterification of fatty acids and transport via chylomicrons to the liver (WU; PALMQUIST, 1991).

It is known that unsaturated fatty acids are generally toxic to gram-positive bacteria. The mechanism might involve a change in cell membrane permeability, which reduces the ability of cells to regulate intracellular $\mathrm{pH}$ and nutrient uptake. Oleic, linoleic, and linolenic fatty acids significantly inhibit the growth of cellulolytic bacteria, such as Butyrivibrio fibrisolvens, Ruminococcus albus, and $R$. flavefaciens, thus reducing the degradability of fiber (NRC, 2001).

The degree of instauration is, possibly, the most important trait that influences digestibility either because it affects the formation of micelles and the movement of fatty acids in the adjacent water layer microvilli of the small intestine (NRC, 2001) or because they are re-esterified faster within the enterocyte, facilitating its removal from the cytosol and thereby increasing the rate of absorption (WU; PALMQUIST, 1991).

In this experiment, the animals fed with linseed showed higherEE digestibility than the control group animals, demonstrating efficiency in the absorption of these lipids, but no effects on dry matter intake or apparent digestibility of DM, NDF, NDA, CP, and TDN were observed. Contrasting results were found by Petit et al. (2002), who observed a reduction ( $p$ $<0.05)$ in the apparent digestibility of DM, NDF, $\mathrm{ADF}$, and EE in dairy cows fed with linseed as grains as compared to animals fed with Megalac $\mathbb{R}$ or micronized soy. The authors further stated that the access by rumen microorganisms or intestinal enzymes was greater in Megalac ${ }^{\circledR}$ fat (calcium soap of fatty acid) and micronized soybean than in linseed, in which fat would be associated with the matrix fiber-protein grain. Differences in the composition of the diet provided to the animals can explain the opposing results. In this experiment, linseed was not combined with another ingredient in the experimental diet.

In the present experiment, the supplementation period was 126 days since, according to Webb et al. (2004), in cattle, preantral follicles (primordial follicle) take approximately three months to grow to the preovulatory follicular stage. Therefore, the hypothesis of this experiment was that the period of ingestion of linseed influenced oocyte development, and we expected an increase in oocyte viability in accordance with the period of supplementation. Two OPUs were performed when theoretically all oocytes would be under the effect of the supplementation. No direct effects of lipid supplementation on AFC were found in Girolando cows supplemented for 126 days with $800 \mathrm{~g}$ of linseed. After seven OPU sessions, no difference was observed in AFC among sessions of cows supplemented or not supplemented with linseed. The effects of the addition of PUFAs in the diet of cattle on AFC are quite controversial, and studies showing positive effects or no effect can be found (BILBY et al., 2006; FOULADI-NASHTA et al., 2009; PONTER et al., 2012; NOGUEIRA et al., 2012).

Additionally, a few similar studies were performed with Bos taurus $\times$ Bos indicus, the main milk breed used in the hottest regions of Brazil. Cavalieri et al. (2005) reported that increased PUFA in the cow's diet increased the number of follicles, 
but this increase appeared to be independent from the fatty acid profile in the diet. Diets rich in linoleic acid, similar to that present in linseed, or with the addition of soybean oil to their formulations increase hepatic gluconeogenesis owing to the increase of rumen propionate production (THOMAS; WILLIAMS, 1996). The increase in gluconeogenesis has been associated with elevations in plasma concentrations of insulin and IGF-1, which are capable of increasing the number of small and medium follicles in Nelore heifers (NOGUEIRA et al., 2012). On the contrary, Bilby et al. (2006) found that supplementing dairy cows with mono and polyunsaturated fatty acids did not lead to a difference in the number of follicles present in the ovaries. Similarly, Guardieiro et al. (2011) observed that the elevation of the circulating concentration of IGF-1 in Nelore heifers supplemented with rumenprotected fat did not increase AFC, confirming the data in the present study.

The results found in the literature reporting the effects of lipid supplementation on oocyte quality are also controversial (BILBY et al., 2006; FOULADI-NASHTA et al., 2009; PONTER et al., 2012; NOGUEIRA et al., 2012). It is believed that such differences are variable depending on the initial body condition of the animals (NOGUEIRA et al., 2012). It has been reported that an increased energy supply in the bovine diet is beneficial for the oocyte quality of animals with moderate BCS and deleterious in animals with high BCS. In the present study, the mean BCS of the cows of both groups was high (4 on a scale of 1 to 5) and the quality rate $(70 \%)$ of the both groups was similar to that found in the literature (NOGUEIRA et al., 2012; FOULADI-NASHTA et al., 2009).

The effect of dietary PUFAs on oocyte quality may be partially mediated by changes in follicular fluid fatty acid composition; that is, the microenvironment surrounding the $\mathrm{COC}$ during its development and maturation (CHILDS et al., 2008; FOULADI-NASHTA et al., 2009). However, changes in the fatty acid composition of oocytes are relatively small, indicating that they have a mechanism of selective uptake of PUFAs (SANTOS et al., 2008).

These changes may influence nuclear maturation and the level of expansion of cumulus cells, critical points for oocyte post-fertilization development (MAREI et al., 2009). In this sense, it can be assumed that even though there is no difference in oocyte viability, oocyte quality might be related to fatty acid composition, especially the phospholipid fraction. However, changes in the lipid profile increase the fluidity of the plasma membrane and consequently show improvement in subsequent early embryonic development, as well as having a beneficial effect on the cryopreservation process by increasing the cryotolerance of these structures (LEÃO et al., 2015; ACCORSI et al., 2016). In other studies from our research group, it has been observed that linseed has low potential for degradability in the rumen, around 20.7\% (CARDOSO et al., $2018 \mathrm{~b}$ ), and when associated with the increase in EE digestibility, it can be inferred that the animals absorbed the fatty acids of linseed. Thus, despite being available in the bloodstream and reaching the follicular microenvironment, the fatty acids are consequently absorbed by the COCs, and thus may not be sufficient to achieve the expected benefits.

In this study, no effect of supplementation was observed on glucose concentrations $(P>0.05)$. These results corroborate those of other authors who provided diets enriched with PUFAs for bovine females (PETIT, 2002; BILBY et al., 2006; NOGUEIRA et al., 2012). Boland et al. (2001) previously documented the importance of glucose as a source of energy for the ovary of bovine females and post-implanted embryos. Owing to the glucoselowering mechanisms of ruminants, effects of treatments on plasma glucose concentrations are not normally expected, which explains the maintenance of glycemia (GAGLIOSTRO; CHILLIARD, 1991).

No differences were found in total plasma albumin concentration between the groups $(P>$ 
0.05). Evaluation of plasma albumin is a way to control the protein intake of food (NOGUEIRA et al., 2012). Although CP consumption was higher $(p<0.05)$ in the LINS group, it was not sufficient to alter plasma albumin concentrations, which remained within the normal range for the species (ECKERSALL, 2008).

The administration of fat to cows stimulates the synthesis and accumulation of cholesterol and cholesterol esters in tissues and body fluids, including in the ovaries (THOMAS; WILLIAMS, 1996; NOGUEIRA et al., 2012). The lipoproteins predominantly present in the bloodstream of ruminants are high-density lipoproteins (HDL), which appear to be the only lipoproteins with access to the intrafollicular compartment (HAWKINS et al., 1995). Ryan et al. (1995) evaluated the number of follicles responsive to superovulatory treatment and the number and quality of embryos produced, providing diets with and without supplementation of soybean oil. The authors observed an increase in the number of mean follicles, total cholesterol concentration, and progesterone in the follicular fluid of heifers receiving supplementation. However, there was no change in the superovulatory response or number or quality of embryos produced. These results confirm the hypothesis of Mihm et al. (2002), who suggested that the increase in the number of follicles recovered could be explained by the increase in plasma and follicular levels of HDL cholesterol owing to the increase in fat intake. HDL cholesterol, which is free in the luteal cells of the granulosa, would stimulate the production of IGF-1 and other growth factors. According to Monniaux et al. (1997), growth factors modulate growth, maturation, and follicular atresia. These factors are determinant in the development of small follicles until they become dependent on gonadotrophins. In the present study, no differences were found in plasma cholesterol concentrations between groups, although there was a trend $(p=0.0507)$ in the correlation of cholesterol with the number of viable oocytes, which suggests a possible effect of cholesterol on oocyte quality, as mentioned above. Considering that $0,8 \mathrm{Kg} / \mathrm{cow} /$ day didn't bring heathy problems and that this animals were with a very good BCS, the increase of this amount could show better results. It is also possible that better results could be seen in lactating cows with a lesser BCS.

Thus, these results suggest the use of PUFAs in the diet of cattle to provide better quality oocytes and embryos. However, it is clear that research on this subject needs to be continued.

\section{Conclusion}

In conclusion, supplementation of Girolando cows with $0.800 \mathrm{~kg} /$ day of linseed did not alter the AFC, quality of oocytes, or glucose, albumin, or cholesterol concentrations. The linseed provided in grain form to Girolando cows did not alter the digestibility of nutrients, except for the ethereal extract.

\section{Acknowledgments}

The authors acknowledge FUNDECT, CNPq and CAPES for the financial support provided for this experiment and UFMS and UCDB for carrying out the analyses.

\section{References}

ACCORSI, M. F.; LEAO, B. C.; ROCHA-FRIGONI, N. A.; PERRI, S. H.; MINGOTI, G. Z. Reduction in cytoplasmic lipid content in bovine embryos cultured in vitro with linoleic acid in semi-defined medium is correlated with increases in cryotolerance. Zygote, Cambridge, v. 24, n. 4, p. 485-494, 2016. DOI: 10.1017/S 0967199415000428

BILBY, T. R.; BLOCK, J.; AMARAL, B. C.; SA FILHO, O.; SILVESTRE, F. T.; HANSEN, P. J.; STAPLES, C. R.; THATCHER, W. W. Effects of dietary unsaturated fatty acids on oocyte quality and follicular development in lactating dairy cows in summer. Journal of Dairy Science, Lancaster, v. 89, n. 10, p. 3891-3903, 2006. DOI: $10.3168 /$ jds.S0022-0302(06)72432-8 
BOLAND, M. P.; LONERGAN, P.; O'CALLAGHAN, D. Effect of nutrition on endocrine parameters, ovarian physiology, and oocyte and embryo development. Theriogenology, Stoneham, v. 55, n. 6, p. 1323-1340, 2001. DOI: 10.1016/S0093-691X(01)00485-X

CAMPBELL, A. G. Grazed pasture parameters. I. Pasture dry-matter production and availability in a stocking rate and grazing management experiment with dairy cows. Journal of Agricultural Science, Cambridge, v. 67, n. 2, p. 199-210, 1966. DOI: $10.1017 /$ S0021859600068283

CARDOSO, C. J. T.; OLIVEIRA JUNIOR, J. S.; KISCHEL, H.; SILVA, W. A. L.; ARRUDA, E. D. S.; SOUZA-CÁCERES, M. B.; OLIVEIRA, F. A. M.; NOGUEIRA, É.; NOGUEIRA, G. P.; MELO-STERZA, F. A. Anti-Müllerian hormone (AMH) as a predictor of antral follicle population in heifers. Animal Reproduction, Belo Horizonte, v. 15, n. 1, p. 12-16, 2018a. DOI: 10.21451/1984-3143-2017-AR887

CARDOSO, C. J. T.; LIMA, A. C. B.; NOGUEIRA, É.; OLIVEIRA, M. V. M.; MELO-STERZA, F. A. Performance and digestive characteristics in dairy cattle maintained under grazing regime and supplemented with linseed. Semina: Ciências Agrárias, Londrina, v. 39, n. 4, p. $1805-1818,2018$ b. DOI: $10.5433 / 1679-0359.2018 v 39$ n4p1805

CAVALIERI, F. B.; SANTOS, G. T.; MATSUSHITA, M.; PETIT, H. V.; RIGOLON, L. P.; SILVA, D.; HORST, J. A.; CAPOVILLA, L. C.; RAMOS, F. S. Milk production and milk composition of dairy cows fed Lac100 ${ }$ or whole flaxseed. Canadian Journal of Animal Science, Ottawa, v. 85 , n. 3, p. 413-416, 2005. DOI: 10.4141/ A04-088

CERRI, R. L.; JUCHEM, S. O.; CHEBEL, R. C.; RUTIGLIANO, H. M.; BRUNO, R. G.; GALVAO, K. N.; SANTOS, J. E. Effect of fat source differing in fatty acid profile on metabolic parameters, fertilization, and embryo quality in high-producing dairy cows. Journal of Dairy Science, Lancaster, v. 92, n. 4, p. 1520-1531, 2009. DOI: $10.3168 /$ jds.2008-1614

CHILDS, S.; CARTER, F.; LYNCH, C. O.; SREENAN, J. M.; LONERGAN, P.; HENNESSY, A. A.; KENNY, D. A. Embryo yield and quality following dietary supplementation of beef heifers with $\mathrm{n}-3$ polyunsaturated fatty acids (PUFA). Theriogenology, Stoneham, v. 70, n. 6, p. 992-1003, 2008. DOI: 10.1016/j. theriogenology.2008.06.008

CLIPES, R. C.; COELHO da SILVA, J. F.; DETMANN, E.; VASQUEZ, H. M.; SCOLFOROI, L.; LOMBARDI, C. T. Avaliação de métodos de amostragem em pastagens de capim elefante (Pennisetum purpureum, Schum) e capim-mombaça (Panicum maximum, Jacq) sob pastejo rotacionado. Arquivo Brasileiro de Medicina Veterinária e Zootecnia, Belo Horizonte, v. 57, n. 1, p. 120-127, 2005. DOI: $10.1590 / \mathrm{S} 0102-09352005000100016$

COCHRAN, R. C.; ADAMS, D. C.; WALLACE, J. D.; GALYEAN, M. L. Predicting digestibility of different diets with internal markers: evaluation of four potential markers. Journal of Animal Science, Lancaster, v. 63, n. 5, p. 1476-1483, 1986. DOI: $10.2527 /$ jas 1986.6351476x

ECKERSALL, P. D. Proteins, proteomics, and thedysproteinemias. In: KANEKO, J. J.; HARVEY, J. W.; BRUSS, M. L. (Ed.). Clinical biochemistry of domestic animals. $6^{\text {th }}$ ed. San Diego: Academic Press, 2008. p. 117-155.

FOULADI-NASHTA, A. A.; WONNACOTT, K. E.; GUTIERREZ, C. G.; GONG, J. G.; SINCLAIR, K. D.; GARNSWORTHY, P. C.; WEBB, R. Oocyte quality in lactating dairy cows fed on high levels of n-3 and n-6 fatty acids. Reproduction, Cambridge, v. 138, n. 5, p. 771-781, 2009. DOI: 10.1530/REP-08-0391

GAGLIOSTRO, G.; CHILLIARD, Y. Duodenal rapeseed oil infusion in early and midlactation cows. 4. In vivo and in vitro adipose tissue lipolytic responses. Journal of Dairy Science,Lancaster, v. 74, n. 6, p. 1830-1843, 1991. DOI: $10.3168 /$ jds.S0022-0302(91)78348-3

GUARDIEIRO, M. M.; BASTOS, M. R.; MOURÃO, G. B.; CARRIJO, L. H. D.; MELO, E. O.; RUMPF, R.; SARTORI, R. Função ovariana de novilhas Nelore alimentadas com dieta suplementada com gordura protegida ruminal. Pesquisa Agropecuária Brasileira, Brasília, v. 45, n. 4, p. 408-414, 2011. DOI: 10.1590/ S0100-204X2010000400009

HAWKINS, D. E.; NISWENDER, K. D.; OSS, G. M.; MOELLER, C. L.; ODDE, K. G.; SAWYER, H. R.; NISWENDER, G. D. An increase in serum lipids increases luteal lipid content and alters the disappearance rate of progesterone in cows. Journal of Animal Science, Lancaster, v. 73, n. 2, p. 541-545, 1995. DOI: $10.2527 / 1995.732541 \mathrm{x}$

HOUGHTON, P.; LEMENAGER, R.; HENDRIX, K.; MOSS, G.; STEWART, T. Effects of body composition, pre-and postpartum energy intake and stage of production of energy utilization by beef cows. Journal of Animal Science, Lancaster, v. 68, n. 5, p. 1447-1456, 1990. DOI: $10.2527 / 1990.6851447 \mathrm{x}$

JENKINS, T. C.; JENNY, B. F. Effect of hydrogenated fat on feed intake, nutrient digestion, and lactation performance of dairy cows. Journal of Dairy Science, Lancaster, v. 72, n. 9, p. 2316-2324, 1989. DOI: $10.3168 /$ jds.S0022-0302(89)79363-2

KIM, J. Y.; KINOSHITA, M.; OHNISHI, M.; AND 
FUKUI, Y. Lipid and fatty acid analysis of fresh and frozen thawed immature and in vitro-matured bovine oocytes. Reproduction, v. 122, n. 1, p. 131-138, 2001. DOI:10.1530/REP.0.1220131

LEÃO, B. C.; ROCHA-FRIGONI, N. A.; CABRAL, E. C.; FRANCO, M. F.; FERREIRA, C. R.; EBERLIN, M. N.; FILGUEIRAS, P. R.; MINGOTI, G. Z. Membrane lipid profile monitored by mass spectrometry detected differences between fresh and vitrified in vitro-produced bovine embryos. Zygote, Cambridge, v. 23, n. 5, p. 732741, 2015. DOI: $10.1017 /$ S0967199414000380

LOPES, C. N.; SCARPA, A. B.; CAPPELLOZZA, B. I.; COOKE, R. F.; VASCONCELOS, J. L. Effects of rumenprotected polyunsaturated fatty acid supplementation on reproductive performance of Bos indicus beef cows. Journal of Animal Science, Lancaster, v. 87, n. 12, p. 3935-3943, 2009. DOI: 10.2527/jas.2009-2201

MAREI, W. F.; WATHES, D. C.; FOULADI-NASHTA, A. A. The effect of linolenic acid on bovine oocyte maturation and development. Biology of Reproduction, New York, v. 81, n. 6, p. 1064-1072, 2009. DOI: 10.1095/ biolreprod.109.076851

MATTOS, R.; STAPLES, C. R.; THATCHER, W. W. Effects of dietary fatty acids on reproduction in ruminants. Reviews of Reproduction, Madrid, v. 5, n. 1, p. $38-45,2000$.

MIHM, M.; CROWE, M. A.; KNIGHT, P. G.; AUSTIN, E. J. Follicle wave growth in cattle. Reproduction in Domestic Animals, Malden, v. 37, n. 4, p. 191-200, 2002. DOI: 10.1046/j.1439-0531.2002.00371.x

MONNIAUX, D.; HUET, C.; BESNARD, N.; CLEMENT, F.; BOSC, M.; PISSELET, C.; MONGET, P.; MARIANA, J. C. Follicular growth and ovarian dynamics in mammals. Journal of Reproduction and Fertility Supplementary, Cambridge, v. 51, p. 3-23, 1997.

NATIONAL RESEARCH COUNCIL - NRC. Nutrient requirements of dairy cattle. $7^{\text {th }}$ ed. Washington: Academic Press, 2001. 381 p.

NOGUEIRA, É.; SILVA, A. S. D.; AMARAL, T. B.; ÍTAVO, L. C. V.; DIAS, A. M.; MINGOTI, G. Z. Follicular dynamics and production of oocytes in young Nellore heifers with energetic supplementation. Revista Brasileira de Zootecnia, Viçosa, MG, v. 41, n. 9, p. 20122017, 2012. DOI: 10.1590/S1516-35982012000900007

NUNES, A. A.; FAVARO, S. P.; GALVANI, F.; MIRANDA, C. H. B. Good practices of harvest and processing provide high quality Macauba pulp oil. European Journal of Lipid Science and Technology, Weinheim, v. 117 , n. 12, p. 2036-2043, 2015. DOI: 10.1002/ejlt.201400577
PALMQUIST, D. L.; JENKINS, T. C. Fat in lactation rations: review. Journal of Dairy Science, Lancaster, v. 63 , n. 1, p. 1-14, 1980. DOI: 10.3168/jds.S00220302(80)82881-5

PETIT, H. V. Digestion, milk production, milk composition, and blood composition of dairy cows fed whole flaxseed. Journal of Dairy Science, Lancaster, v. 85 , n. 6 , p. $1482-1490,2002$. DOI: $10.3168 /$ jds.S00220302(02) 74217-3

PETIT, H. V.; DEWHURST, R. J.; SCOLLAN, N. D.; PROULX, J. G.; KHALID, M.; HARESIGN, W.; TWAGIRAMUNGU, H.; MANN, G. E. Milk production and composition, ovarian function, and prostaglandin secretion of dairy cows fed omega-3 fats. Journal of Dairy Science, Lancaster, v. 85, n. 4, p. 889-899, 2002. DOI: $10.3168 /$ jds.S0022-0302(02)74147-7

PONTER, A. A.; GUYADER-JOLY, C.; NUTTINCK, F.; GRIMARD, B.; HUMBLOT, P. Oocyte and embryo production and quality after OPU-IVF in dairy heifers given diets varying in their $\mathrm{n}-6 / \mathrm{n}-3$ fatty acid ratio. Theriogenology, Stoneham, v. 78, n. 3, p. 632-645, 2012. DOI: 0.1016/j.theriogenology.2012.03.009

RYAN, D. P.; BAO, B.; GRIFFITH, M. K.; WILLIAMS, G. L. Metabolic and luteal sequelae to heightened dietary fat intake in undernourished, anestrous beef cows induced to ovulate. Journal of Animal Science, Lancaster, v. 73, n. 7, p. 2086-2093, 1995. DOI: 10.2527/1995.7372086x

SANTOS, J. E.; CERRI, R. L.; SARTORI, R. Nutritional management of the donor cow. Theriogenology, Stoneham, v. 69 , n. 1, p. 88-97, 2008. DOI: $10.1016 /$ j. theriogenology.2007.09.010

SARTORI, R.; GIMENES, L. U.; MONTEIRO JUNIOR, P. L.; MELO, L. F.; BARUSELLI, P. S.; BASTOS, M. R. Metabolic and endocrine differences between Bos taurus and Bos indicus females that impact the interaction of nutrition with reproduction. Theriogenology, Stoneham, v. 86 , n. 1 , p. $32-40$, 2016. DOI: $10.1016 /$ j. theriogenology.2016.04.016

SILVA, D.; QUEIROZ, A. C. Análise de alimentos: métodos químicos e biológicos. Viçosa, MG: UFV, Impr. Univ., 1981. 166 p.

STAPLES, C. R.; BURKE, J. M.; THATCHER, W. W. Influence of supplemental fats on reproductive tissues and performance of lactating cows. Journal of Dairy Science, Lancaster, v. 81, n. 3, p. 856-871, 1998. DOI: 10.3168/jds.S0022-0302(98)75644-9

THANGAVELU, G.; COLAZO, M. G.; AMBROSE, D. J.; OBA, M.; OKINE, E. K.; DYCK, M. K. Diets enriched in unsaturated fatty acids enhance early embryonic development in lactating Holstein cows. Theriogenology, 
Stoneham, v. 68, n. 7, p. 949-957, 2007. DOI: 10.1016/j. theriogenology.2007.07.002

THOMAS, M. G.; WILLIAMS, G. L. Metabolic hormone secretion and FSH-induced superovulatory responses of beef heifers fed dietary fat supplements containing predominantly saturated or polyunsaturated fatty acids. Theriogenology, Stoneham, v. 45, n. 2, p. 451-458, 1996. DOI: $10.1016 / 0093-691 X(95) 00381-\mathrm{H}$

VAN SOEST, P. J.; ROBERTSON, J. B.; LEWIS, B. A. Methods for dietary fiber, neutral detergent fiber, and nonstarch polysaccharides in relation to animal nutrition. Journal of Dairy Science, Lancaster, v. 74, n. 10, p. 35833597, 1991. DOI: 10.3168/jds.S0022-0302(91)78551-2
WEBB, R.; GARNSWORTHY, P. C.; GONG, J. G.; ARMSTRONG, D. G. Control of follicular growth: local interactions and nutritional influences. Journal of Animal Science, Lancaster, v. 82, p. E63-E74, 2004. Supplement 13. DOI: $10.2527 / 2004.8213$ _supplE63x

WU, Z.; PALMQUIST, D. L. Synthesis and biohydrogenation of fatty acids by ruminal microorganisms in vitro. Journal of Dairy Science, Lancaster, v. 74, n. 9, p. 3035-3046, 1991. DOI: 10.3168/ jds.S0022-0302(91 )78489-0

ZERON, Y.; SKLAN, D.; ARAV, A. Effect of polyunsaturated fatty acid supplementation on biophysical parameters and chilling sensitivity of ewe oocytes. Molecular Reproduction and Development, New York, v. 61, n. 2, p. 271-278, 2002. DOI: 10.1002/ mrd.1156 